\title{
În numele tatălui. Un mit personal dostoievskian
}

\author{
Călin-Horia Bârleanu ${ }^{\mathbf{A} *}$ \\ Facultatea de Litere și Științe ale Comunicării, Universitatea "S, Stefan cel Mare", Str. Universității 13, 720229 Suceava, România
}

\begin{abstract}
Despre articol
Istoric:

Primit 26 februarie 2021

Acceptat 1 aprilie 2021

Publicat 18 august 2021

Cuvinte-cheie:

psihocritică

figură paternă

erou

complex

Rezumat

De numele lui Dostoievski se leagă, deja, aproape la fel de multe mituri, unele în legătură cu opera, altele în raport direct cu viața scriitorului. Fără să-i poată umbri, însă, din strălucire, cu atît mai mult cu cît adevărata dimensiune a marii sale opere nu încetează să-şi dezvăluie secretele și sensurile. Concentrat în multe dintre capodoperele sale pe figura paternă, proiectată la modul manifest sau uneori, într-un registru latent, scriitorul rămîne captiv propriilor sale subterane, din care își extrage creativitatea, sublimînd fără îndoială, o suferință. Iar acea suferință se pare că a încercat-o, în mod constant pe tot parcursul vieții. Țesătura simbolică a operei dezvăluie o adevărată rețea tematică în care figura tatălui domină asemenea unei divinități, de cele mai multe ori, indiferente și absente.
\end{abstract}

Psihocritica lui Charles Mauron a fost cea care a deschis, dincolo de sugestiile psihanalitice freudiene, în anul 1962, calea spre o nouă formulă de a citi și înțelege atît textul, cît și pe creatorul lui. Propunerea eseistului și criticului francez a stîrnit, într-un spațiul cultural cu mult mai tolerant, reacții dintre cele mai vii, mai ales pe fondul unei susținute campanii, duse de Jaques Lacan, privind dimensiunile și aplicabilitatea psihanalizei. În comparație, în anul în care în România apărea Mihail Eminescu din punct de vedere psihanalitic (Vlad, 1932), reacțiile au trecut cu mult peste limita discursului academic sau specific cercetării. Fără ancore care să îngusteze sau să limiteze, în orice un fel, orizontul cunoașterii operei literare, cu atît mai mult cu cît psihanaliza a demonstrat abilitatea de a descoperi prin instrumentele sale, noi căi de interpretare, perspective și concepte (cum ar fi existența unei vieți pulsionale, actele ratate sau influența inconștientului asupra procesului de comunicare), psihocritica s-a bucurat de un context fertil, în așteptarea unui nou limbaj care să ofere, pînă la urmă, o voce și celor interesați de dimensiunile profunde ale operei artistice.

Evident, un demers psihocritic în orice operă literară trebuie susținut, tocmai pentru realizarea eficientă a suprapunerii textelor şi a revelării figurilor obsedante care construiesc mitul personal, printr-o formă de acces la viața scriitorului, acolo unde creația rămîne proiect și se află în permanentă stare embrionară. În cazul lui Dostoievski, un avantaj important vine prin munca de traducere a cercetătorului și universitarului ieșean Leonte Ivanov (Dostoievski, 2018). Scrisori I (1837-1859), acoperind poate cea mai importantă perioadă din viața adolescentului și tînărului care avea să devină cel mai cunoscut și mai influent scriitor rus, arată un tipar ideologic care plasează figura paternă într-o zonă în care comunicarea se face prin intermediul unor mărci prestabilite și care evocă o puternică autoritate paternă. Aproape fără excepție, scrisorile tînărului Feodor Mihailovici se încheie în aceeași notă, prin care se poate vedea atît un tipar social specific vremii, cît și o formă de dependență pe care adolescentul a resimțit-o ca pe o presiune. De pildă, o scrisoare din anul 1837, cînd Dostoievski avea șaisprezece ani, se încheie: „Cu sincer respect și afecțiune filială, avem onoarea să fim ai dv. copii” (Dostoievski, 2018, p. 43) (referindu-se și la fratele său Mihail). Iar într-o altă scrisoare, din același an: „Cu adînc respect și supunere rămînem ai dv. Mihail şi Feodor Dostoievski, care vă iubesc sincer” (p. 46).

Rațiunile economice, la care scrisorile fac de cele mai multe ori referire, tinerii avînd diferite nevoi specifice școlii, încadrează stilul epistolar destinat tatălui într-o matriță cît se poate de rigidă, dar care

*Adresă de corespondență: calin.barleanu@gmail.com. 
dispare complet în orice altă scrisoare. Atît de frapantă pare diferența dintre scrisorile pe care i le trimite Feodor Pavlovici tatălui și cele trimise fratelui său, încît dragostea filială invocată sau respectul, întotdeauna adînc și chiar „pînă la mormînt” (Dostoievski, 2018, p. 50) începe să își arate și alte dimensiuni. Dacă analizăm imaginea paternității, inclusiv la nivelul operei dostoievskiene de mai tîrziu, ne vedem în fața unui adevărat complex care își găsește răspuns, inițial, în graba cu care tînărul alege să abandoneze studiile militare pe măsură ce moartea tatălui îl eliberează de piedicile morale. În afară de faptul că, după decesul lui Mihail Andreevici Dostoievski, tînărul se referă doar de cîteva ori la amintirea tatălui, îi scrie fratelui său, cînd acesta trăia încă, la doar șaptesprezece ani, în anul 1838, cuvinte care, în profund contrast cu iubirea şi respectul filial absolut, reflectă o altă realitate: „mi-e milă de sărmanul tata! Ciudat caracter! [...] Dar ai observat? Tăticul nu cunoaște absolut deloc lumea: a trăit în ea vreme de cincizeci de ani și a rămas cu aceeași părere despre oameni [...]. Fericită ignoranță.” (p. 74).

Distanța dintre stilurile pe care tînărul Dostoievski le folosește, în scrisorile spre tată și în cele spre fratele său, este nu doar vizibilă, ci chiar frapantă, în multe locuri. Libertatea de a se exprima și autenticitatea sentimentelor exprimate se reflectă cu simplitate în fiecare rînd, fără efuziuni exagerate sau menite să convingă, demonstrativ, că toate cele scrise sînt și reale. Scrisorile spre fratele său poartă cu adevărat amprenta afecțiunii necondiționate: „O, ce mult, ce mult a trecut de cînd nu ți-am scris, scumpul meu frate... Dezgustător examen!” (Dostoievski, 2018, p. 70). Permanenta invitație de a-i scrie înapoi, care însoțește fiecare scrisoare destinată lui Mihail, susține nevoia adolescentului de a rămîne în contact cu familia sa, de a-şi comunica liber adevăratele și, deocamdată, ascunsele trăiri şi aspirații pentru viitor.

Opera literară dostoievskiană a rămas, pentru cei mai mulți dintre comentatorii săi, un reper mai ales în privinţa conflictului cu figura paternă. Discursul analitic susţinut de psihocritică sau de psihanaliză s-a orientat, în nenumărate pagini deja, spre felul în care autoritatea paternă este construită la nivelul ficțiunii textului. Ficțiunea despre care atît psihocritica, cît și psihanaliza au scris, referindu-se la relația cu capacitatea artiștilor de a construi imagini, fantasme, sau, altfel spus, de a visa cu ochii deschiși, are o importantă rădăcină în inconștient, acolo unde, conform psihanalizei jungiene, se află miturile fundamentale ale omenirii, conflictele și temele intime ale existenței umane, sub forma simbolurilor și a arhetipurilor culturale.

În privința felului în care a fost percepută autoritatea paternă în cadrul marii literaturi universale, (figurile zeilor, ecouri ale vieții inconștiente, fiind adesea lezate de iubirea sau de libertatea oamenilor de a acționa, frustrîndu-le astfel sentimentul superiorității și al nemuririi), complexul Oedip a fost discutat întotdeauna, în abordările psihanalitice, prin intermediul conflictului specific cu figura paternă. În ciuda faptului că, din faimosul concept freudian a rămas, pînă astăzi, doar o înţelegere trunchiată a dinamicii umane inconștiente, componenta conflictuală specifică nu poate fi ignorată. În acest sens, reducerea complexului oedipal la iubirea băiatului pentru mama sa nu este decît o eroare, mai ales prin ignorarea dimensiunii inconștientului colectiv. Mircea Eliade vedea în simbolul mamei, central în mit, dar și în structura complexului psihologic, un ecou pentru ceea ce psihanaliza a numit pulsiunea de viațăa: „propriuzis Imaginea Mamei este adevărată, iar nu o mamă sau alta [și] această dorință exprimă mai multe lucruri în același timp, pentru că ea este dorința de a reintegra starea de beatitudine a Materiei vii” (Eliade, 1994, p. 18-19).

Apărut în anul 1875, romanul tradus în limba română cu titlul Adolescentul, a rămas, ca parte a marilor romane dostoievskiene și, cu siguranță, cel mai controversat. Dezbaterea vine tocmai din faptul că orice detentă metafizică, specifică literaturii scriitorului, aproape că lipsește aici, fără îndoială și prin felul în care personajul central este proiectat. Sub forma unui proces de rememorare, „m-am apucat să aștern pe hîrtie această istorie a primilor mei paşi pe drumul vieții...” (Dostoievski, 2019, p. 7), tînărul Arkadi Andreevici stabilește de la bun început tonul întregului roman, atins de frustrare. Aici, vom aminti și un aspect psihologic a ceea ce Marthe Robert numea „romanul bastardului”: „trec, aşadar, drept fiul lui legitim, deși sînt un bastard în toată puterea cuvîntului” (p. 8).

Legal, fiu al unui fost iobag, Makar Ivanov Dolgoruki, este crescut de un tată absent, moșierul Varsilov, asupra căruia își concentrează adolescentul aproape cele mai multe dintre energiile sale. Abandonat de ta- 
tăl natural, este ignorat aproape complet și de cel în compania căruia crește, cu toate că prezența autorităţii paterne lipsește la modul aproape absolut din viața lui Arkadi. Sub amprenta unui abandon repetat, tînărul dezvoltă o puternică opoziție față de imaginea paternității, vizibilă prin detalii directe: „rar a fost cineva atît de supărat pe numele lui, cum sînt eu de cînd mă știu” (Dostoievski, 2019, p. 9).

Vom observa aşadar că Dostoievski nu se ferește să pună reflexele psihologice ale eroului în lumina cît mai clară a celui mai simplu demers de lectură. Experiențele sale, limitate, dar cu puternic impact asupra stimei de sine și a felului în care se percepe ca entitate, nedorită sau abandonată în mod repetat, construiesc un discurs morbid, susținut de pulsiunea de moarte, pe alocuri chiar masochist. Blocat între cele două figuri masculine, la fel de absente, Arkadi o alege totuși, ca reper, pe cea care pare mai compatibilă cu universul său ideologic. Ca dovadă, în cele din urmă, tatăl și fiul ajung să aibă sentimente pentru aceeași femeie. „Versilov, tatăl meu, pe care nu-l văzusem decît o singură dată la vîrsta de zece ani” (Dostoievski, 2019, p. 19) este și cel asupra căruia imaginația copilului se aruncă pentru a completa nu golurile, ci marele gol [s. n.], reprezentînd imaginea paternității. Perceput ca „rece și trufaș, disprețuitor şi indiferent faţă de mine...” (p. 19), Versilov nu pare să fie, de fapt, decît în prea mică măsură asemeni felului în care îl percepe fiul său.

Căutarea neobosită a figurii tatălui, ca nevoie psihologică de care a fost în mod repetat privat, îl apropie pe Arkadi de bătrînul prinț Sokolski. Imaginarul dostoievskian filtrează inclusiv arhetipurile specifice inconștientului colectiv, pentru că figura bătrînului înțelept, prezentă în toate spațiile culturale și aproape în toate momentele evoluției omului este, în cazul de față, modificată. Și, chiar dacă reprezintă, pentru tînărul abia ajuns în oraș, un ajutor pe care nu îl poate percepe și nici înțelege la adevărata valoare, arhetipul bătrînului, prin personajul prințului, pare capabil să ajute pe oricine cu excepția protagonistului. Astfel, prin precizarea că „De douăzeci și cinci de ani tot mărita fete [...] le creștea cu dădace și guvernante franțuzoaice, apoi le dădea la cele mai bune școli, și în cele din urmă le mărita cu zestre" (Dostoievski, 2019, p. 26), este descris prințul, ca o adevărată forță civilizatoare pentru toți cei care interacționează cu el, mai puțin pentru Arkadi care, într-o căutare compulsivă, este incapabil să-și potolească nevoia de prezența tatălui. Iată, de pildă, că în afara vîrstei despre care se presupune că este aproape un simbol al conflictului, Arkadi are motive mult mai subtile pentru a exagera comportamental de atîtea ori. Supărat sau stingherit peste măsură, uneori de o simplă privire, explodînd furios sau cu o pasiune nejustificată de tema în discuție, adolescentul arată într-o manieră cît se poate de subtilă că absența autorității paterne este și cea care a facilitat o asemenea dezvoltare ideologică.

Pe de altă parte, imaginea puternică a tatălui, ca simbol absolut al pulsiunii de viață, generator al existenței, poate fi intuită și în alte texte dostoievskiene. În acest context, vom observa și cît de bine amintește de personajul central din Însemnări din subterană următorul fragment: „Sînt un om slab, care cedează uşor în lucrurile mici [...]. Toate acestea mi se trag din lipsa mea de stăpînire și din faptul că am crescut în umbră [...], prefer pînă în ziua de azi să mă retrag în colțul cel mai întunecat!” (Dostoievski, 2019, p. 31).

Finețea perspectivei psihologice dostoievskiene este vizibilă mai degrabă prin intermediul întregii opere, decît printr-un singur text. Ceea ce propunea Mauron, aşadar, cere în cazul de faţă o formă de inițiere în complexul univers proiectat în operă de Dostoievski, astfel încît mitul personal, cristalizat pe figura tatălui, apare mai clar atunci cînd, dincolo de Arkadi, putem citi și despre felul în care tatăl Karamazov șia abandonat fiii, legitimi sau nu. Absența autorităţii despre care psihanaliza susținea că are un rol decisiv în conturarea poziției faţă de divinitate, părinții reprezentînd figuri în care copiii investesc inconștient seturi de credințe și de așteptări, modelează tipare umane similare în opera lui F.M. Dostoievski, dar și dincolo de ea. De la Arkadi la Fraţii Karamazov, tipul psihologic proiectat de scriitorul rus este cît se poate de similar. Neîncrederea este înlocuită doar cu cele mai ferme convingeri, care ajung să-i alieneze pe eroi. Ivan și Mitea Karamazov sînt consumați de modul în care percep lumea și pe ei înșiși, fiind și absolut convinși de realităţile pe care le percep.

Pierdut într-un ateism a cărui pasiune sugerează mai degrabă nevoia de a crede, Ivan Karamazov, posesor al rațiunii și al argumentului, se află la finalul romanului la limita care marchează o alienare fără 
întoarcere. Aleoșa, pe de altă parte, cizelat de creștinism și mai cu seamă de viața monahală, în stăpînirea propriilor emoții, înlocuiește figura paternă inexistentă cu una care, prin destinul tragic rezervat marilor personaje, îl părăsește aruncîndu-l într-o deznădejde imposibil de explicat pe cale rațională. Fugit din mănăstire după ce trupul starețului Zosima începe să se descompună, spre stupoarea generală, Aleoșa se lasă pradă unei disperări care poate fi înțeleasă doar prin detaliile psihologice, esențiale întregii literaturi dostoievskiene. „Nu mă răzvrătesc împotriva lui Dumnezeu, însă nu vreau să «accept lumea » așa cum a creat-o el, atîta tot" (Dostoievski, 1993, p. 584), răspunde mezinul Karamazov cînd este observat sprijinit de un copac, în afara mănăstirii, vulnerabil poate pentru prima dată cu adevărat în rolul său de erou salvator. Surprins într-un Ghetsimani posibil doar prin sentimentul abandonului, intim cunoscut tuturor fraților Karamazov, Aleoșa suferă o formă de „dedublare” temporară, despre care oricum Dostoievski a arătat încă de la începutul carierei sale, prin romanul Dublul, publicat în anul 1846, că o înțelege în profunzime. Gata să accepte orice propunere din partea oportunistului Rakitin, de a petrece cu mîncare și băutură, chiar în compania femeilor, la polul opus „ideii” sub care și-a construit întreaga sa existență, ghidat de figura luminoasă a starețului Zosima, tînărul se vede privat de cel mai important reper al existenței sale.

Se cuvine să menționăm aici că fuga mezinului Karamazov din mănăstire are loc într-un context spiritual, capitolul Dubul putreziciunii concentrîndu-se pe reacțiile stîrnite nu doar de moartea atît de îndrăgitului preot și duhovnic, ci mai cu seamă de felul în care corpul acestuia intră într-un proces firesc, dar incompatibil cu așteptările superficiale ale lumii însetate după semnele divinului. În plan latent, însă, Aleoșa respinge o formă de organizare sau, altfel spus, un destin care, independent de voința sa, îl include de fiecare dată. Poate mai mult decît toți ceilalți frați Karamazov, Aleoșa își pierde tatăl simbolic, de cele mai multe ori. Pendulînd între viața în mănăstire și tatăl său, iubindu-i în egală măsură și prețuindu-i conform dogmei creștine, îi pierde totuși pe amîndoi. Starețul moare într-un fel mult prea specific lumii, în vreme ce tatăl natural este ucis, de unde se naște și revolta tînărului în fața unor evenimente implacabile, dar pe care le percepe prin intermediul sentimentului de abandon. Ordinea lumii, așa cum este ea, în care trebuie să accepte necondiționat pierderea este, pentru tînărul Karamazov, prea mult.

Prin urmare, vom observa că Dostoievski a pregătit tipologia fiului abandonat, care se și răscoală în fața nedreptății pe care trebuie să o și poarte asemeni unui stigmat pentru totdeauna, încă din momentul cînd l-a proiectat pe Arkadi, fără loc și reper într-o lume atît de generoasă cu figurile paterne. Momentul de rătăcire al lui Aleoșa are un corespondent în cele mai multe dintre acțiunile lui Arkadi care se aventurează în comportamente mult prea nepotrivite dorințelor sale de a reuşi social, implicîndu-se și devenind un model pentru toți ceilalți. De la serile în care bea fără să se poată opri, la jocul de noroc, despre care Dostoievski a scris proiectîndu-și bogata și dramatica sa experiență în domeniu, sau ascuns într-o cameră de unde ascultă conversația unor femei, și pînă la momentele în care își pierde cumpătul și se răstește la cei cu care dialoghează, adolescentul dovedește aceeași lipsă, acut resimțită, a autorității paterne.

Tatăl, pe de altă parte, spre care discursul scriitorului se îndreaptă de atîtea ori, ca spre un simbol al vitalității, principiu generator al vieții, are în cele mai multe dintre textele lui Dostoievski aceleaşi trăsături morale. De la Eternul soț (Dostoievski, 1968), unde cei doi bărbați, rivali, Alexei Ivanovici Velceaninov și Pavel Pavlovici Trusoțki se luptă pentru un ascendent psihologic, indiferenți chiar și în privința Lizei, fiica lui Velceaninov, dar crescută de Trusoțki, la Adolescentul și, în cele din urmă, la ultima capodoperă literară, Frații Karamazov, imaginea paternității are trăsături similare, iar deseori chiar identice. O formă de indiferență marchează relația tatălui cu copiii săi, chiar dacă necesităţile vitale vieții sînt respectate de la bun început dar, de regulă, numai prin intermediari. Mai mult, vom observa şi că, oricît de alienat este bătrînul tată Karamazov, cu fiecare dintre copiii săi, alege totuși să-l țină aproape pe Smerdeakov. Latura morbidă a tatălui, folosindu-și fiul vitreg ca servitor, umilindu-l adesea, primește un răspuns în cele din urmă prin răscoala tuturor fiilor. Vina colectivă, despre care Dostoievski a scris un adevărat poem în cadrul ultimului său roman, este cu deosebită prudență infiltrată în orizontul trăirilor fraţilor Karamazov. Dmitri recunoaște deschis că îi dorește moartea lui Feodor Pavlovici, tatăl său, Ivan pleacă din localitate într-un moment deosebit de tensionat, lăsînd indirect cale liberă oricăror intenții spre tată, iar Aleoșa, într-o bunătate iluzorie, se amăgește și respinge un scenariu care se produce inevitabil. 
Figura tatălui, de la registrul mitologic și pînă la cel inconștient imposibil de ignorat, apare în opera lui Dostoievski de la bun început, chiar și acolo unde vîrsta eroilor sau dinamica socială nu ar putea sugera sau susține o asemenea apariție, fie ea și metaforică. În Dublul, scindarea domnului Goliadkin devine un prilej pentru ca mitul personal dostoievskian să se poată manifesta, astfel încît scriitorul își numește cei doi eroi „Goliadkin senior” și „Goliadkin junior”, referindu-se la cel nou apărut, dublul. Înlocuirea lui Goliadkin senior, treptată și totuşi aparent imposibil de oprit în nici un moment, devine în cadrul unei lecturi psihocritice un argument în plus pentru ceea ce Freud a numit dorință inconștientă specifică psihologiei fiului (Freud, 1999, p. 285). Interesează aici, fără îndoială, tocmai felul în care pentru scriitorul rus figura paternă este de cele mai multe ori, la fel. Absența tatălui provoacă un şir de acțiuni care îl alienează pe erou pentru a-l purifica, trecindu-l printr-o serie nemiloasă de experiențe pentru care nu a fost niciodată pregătit. Prin cel mai simplu proces de „suprapunere” (Mauron, 2010, p. 33) a textelor, după cum îl numea Mauron, poate fi observată o fantezie imaginativă specifică simbolismului paternității: „în imaginație, sufletul care se construiește se joacă și își rejoacă propria istorie, amestecînd amintiri și proiecte..." (Mauron, 2010, p. 106). Suprapunerea dezvăluie rețele care se cristalizează în cele din urmă în figuri sau simboluri fundamentale în economia creației oricărui artist.

Romanul Adolescentul reprezintă un reper esențial atunci cînd se evocă figura tatălui ca parte a mitului personal dostoievskian și pentru că eroul, perfect proiectat pentru a servi întocmai unui scop inconștient, este blocat într-o tranziție psihologică fără catharsis. „Deși depăşisem vîrsta copilăriei”, susține Arkadi, surprins în plin proces de metamorfozare, „m-am purtat totuși ca un copil, ceea ce dovedea că în sufletul meu [...] mai dăinuiau încă pornirile copilului...” (Dostoievski, 2019, p. 291). Zbuciumul interior al protagonistului are un evident ecou în inconstanța planurilor și deciziilor sale, permanent supuse presiunilor interioare pe care le percepe, de obicei, doar atunci cînd efectele au devenit palpabile și, ca urmare, imposibil de anulat. Pus în fața unor pulsiuni pentru care nu găsește nici un fel de corespondent spre a le înțelege, singur deoarece autoritatea paternă 1 -a îndepărtat de prea multe ori, eroul se găsește în fața dualității umane, despre care Dostoievski se pare că nu a încetat să scrie, de fapt, niciodată: ,,...n-am reușit să dezleg această taină uimitoare: cum de pot oamenii [...] să nutrească în sufletul lor idealul cel mai înălțător alături de cea mai odioasă josnicie, și ambele cu sinceritate deplină” (Dostoievski, 2019, p. 379).

Figura paternă și, mai ales, numele între care oscilează și de care se rușinează atunci cînd este prezentat, este pînă în final, pentru adolescent, prilej de introspecție. Absența tatălui și mai ales a suportului acestuia, în cele mai importante etape ale existenței sale, amprentează procesele tînărului care se aventurează în societate animat de convingeri nefondate și adesea chiar superficiale. În acest sens, vom observa că, întro formă diferită, atît în Adolescentul, cît și în Frații Karamazov, Dostoievski propune opere centrate pe aceeași figură simbolica a tatălui:

„Cînd mi-am dat seama cît de puțin îl cunoșteam pe acest om, pe care mă grăbisem să-l condamn, am plecat rușinat în camera mea. Trebuie să mărturisesc că tocmai în perioada aceea eram mai nedumerit ca oricînd în privința lui. Încă niciodată nu mi se păruse atît de complicat și de enigmatic ca atunci. De altfel, asta m-a și determinat să scriu această poveste.” (Dostoievski, 2019, p. 410).

Așadar, întregul proces de cunoaștere al scriitorului rus orbitează în jurul figurii tatălui, în care adolescentul investește constant, hiperbolizînd și construind enigme acolo unde imaginarul său nu putea încă să ajungă. Iar finalul abrupt al romanului arată că enigmaticul părinte este, de fapt, îndrăgostit și chiar o cere în căsătorie pe femeia aleasă, indiferent față de femeia care trece drept soția sa sau față de Arkadi care îl privește ca pe un tată.

Reputatul cercetător Leonte Ivanov spunea că „Dostoievski a știut să desfacă lacătele ce zăgăzuiau drumul către sufletul omenesc și să le vorbească oamenilor despre problemele general-umane” (Ivanov, 2014). Marile teme, între care se află nu doar paricidul, ci și figura complexă a tatălui, ca generator al demersului creator, au atras generații nenumărate de cititori și comentatori, pregătiți să ajungă, prin opera literară, 
la o nouă și poate mai profundă cunoaștere a sinelui. Propunerile lui Freud, exprimate în Dostoievski și paricidul (Freud, 1999, p. 292-294), chiar dacă mult prea orientate spre patologicul creatorului și prea puțin concentrate pe dimensiunile operei sale, păstrează sclipirea viziunii psihanalistului. Un exemplu în acest sens ar fi tocmai prioritatea pe care o acordă cercetătorul inconștientului copilăriei și adolescenței scriitorului rus. Freud susținea, în raport cu atît de discutatele crize epileptice dostoievskiene, că acestea ar fi avut debutul „doar după trăirea zguduitoare de la optsprezece ani cînd tatăl său a fost ucis” (Freud, 1999, p. 293).

Astăzi, nenumărate generații de biografi și critici au pus la îndoială finalul atît de dramatic al tatălui celui care avea să devină unul dintre cei mai influenți scriitori ai lumii. Cu toate acestea, decesul tatălui, ca principal reper al Supraeului, în jurul figurii căruia se cristalizează viitoarele reguli și interdicții ale adultului, nu poate trece fără consecințe, cu atît mai mult cu cît de figura paternă se leagă orientarea tînărului spre școala militară, după cum, la foarte scurt timp, dispariția tatălui marchează și o radicală schimbare de carieră, tînărul Feodor Mihailovici renunțînd la studii și la cariera sa. Crizele epileptice de care ar fi suferit scriitorul, sugerau pentru Freud, „o identificare cu un mort, cu o persoană care într-adevăr a murit sau care mai trăiește, dar căreia respectivul îi dorește moartea” (Freud, 1999, p. 294).

Prin urmare, geniul lui Dostoievski, după cum sugerează şi Leonte Ivanov, este în legătură cu realul orizontului uman şi nu cu idealul sau dezirabilul. Scriitorul rus a sondat la adîncimi atît de importante în inconștientul personal încît a descoperit o voce universală, independent de limbajul sau cultura în care s-a format. Și, indiferent de destinul tatălui, figurile paterne dostoievskiene au trăsături similare, printr-o alienare vizibilă față de orice sentimente de dragoste, de apreciere ori chiar de suport omenesc.

\section{Bibliografie}

Dostoievski, F.M. (1962). Idiotul, roman în patru părți, în românește de Tamara și Nicolae Gane, prefață de G. Fridlender, Editura pentru Literatură Universală, București.

Dostoievski, F.M. (1968). Opere, vol. 4, Romane, nuvele și povestiri (1862-1869), literary criticism by Ion Ianoşi, Editura pentru Literatură Universală, București.

Dostoievski, F.M. (1993). Frații Karamazov, roman în patru părți și epilog, vol. 2, traducere de Ovidiu Constantinescu și Isabella Dumbravă, Editura Cartea Românească, București.

Dostoievski, F.M. (2018). Scrisori I (1837-1859), ediție îngrijită, traducere, note și studiu introductiv de Leonte Ivanov, Editura Polirom, Iași.

Dostoievski, F.M. (2019). Adolescentul, traducere din limba rusă de Emma Beniuc, Editura Art, București.

Eliade, M. (1994). Imagini și simboluri. Eseu despre simbolismul magico-religios, prefață de Georges Dumézil, traducere de Alexandra Beldescu, Editura Humanitas, București.

Freud, S. (1999). Opere, vol. 1, Eseuri de psihanaliză aplicată, traducere de Vasile Dem. Zamfirescu, Editura Trei, București.

Ivanov, L. (2014). Două din premisele „marii literaturi”, în „Analele Științifice ale Universității «Al. I. Cuza» Iași”, secțiunea III-e, tomul LX, p. 157-161.

Mauron, Ch. (2010). De la metaforele obsedante la mitul personal, traducere din limba franceză de Ioana Bot, Editura Dacia, Cluj-Napoca.

Vlad, C. (1932). Mihail Eminescu din punct de vedere psihanalitic, Editura Cartea Românească, București. 